\title{
Chops and Chamber Pots: \\ Satire of the Experimental Report in Seventeenth-Century England
}

\author{
Ivana Bičak
}

On the evening of 15 February 1672, Robert Boyle (1627-1691), one of the founders of the Royal Society, observed a curious natural phenomenon in his London home:

\begin{abstract}
Yesternight when I was about to go to bed, an Amanuensis of mine, accustom'd to make Observations, informed me, that one of the Servants of the house, going upon some occasion into the Larder, was frighted by something of Luminous that she saw (notwithstanding the darkness of the place,) where the meat had been hung up before: Whereupon suspending for a while my going to rest, I presently sent for the meat into my Chamber, and caused it to be placed in a corner of the room capable of being made considerably dark, and then I plainly saw, both with wonder and delight, that the joint of meat did in divers places shine like rotten Wood or stinking Fish [...]. ${ }^{1}$
\end{abstract}

The perceived effect was due to bioluminescence, emission of light by a living organism, in this case photobacteria. ${ }^{2}$ The above introduction to this natural phenomenon brings the reader into the private rooms of the experimental philosopher's residence. The discovery and the subsequent inquiry are made in the nocturnal privacy of Boyle's home in Pall Mall. ${ }^{3}$ In the context of the early modern experiment, 'private' does not mean 'solitary' for it frequently includes the presence of laboratory technicians or servants. The latter group constituted 'a perennial hindrance in the quest for privacy' in early modern

1 Boyle Robert, "Some Observations about Shining Flesh", Philosophical Transactions 7.89 (16 Dec 1672) 5108. Unless otherwise stated, all emphasis in quotations is found in the original.

2 Boyle made extended studies of the chemistry of luminescence, including diamonds, shining wood, fish, flesh, glow-worms, and phosphorus. For an extensive history, see Harvey E.N., A History of Luminescence: From the Earliest Times Until 1900 (Philadelphia, PA: 1954).

3 In 1668, Boyle left his Oxford residence and moved into his sister Katherine's house on the south side of Pall Mall.

(C) IVANA BIČAK, 2022 | DOI:10.1163/9789004153073_013

This is an open access chapter distributed under the terms of the CC BY-NC-ND 4.o license, Bičak - 9789004153073 
homes, ${ }^{4}$ in Linda A. Pollock's evocative description. Although omnipresent in elite households, servants could not provide valid testimonies owing to their social standing. Hence, as there are not enough reliable witnesses who could certify the available empirical data 'at so inconvenient an hour, ${ }^{5}$ Boyle composes an exhaustive report of circumstantial detail surrounding this shining piece of meat. He then publishes his 'theatre of fact', as Al Coppola aptly calls it, ${ }^{6}$ in the Society's official journal, Philosophical Transactions.

In the development of seventeenth-century science, the notions of privacy regularly spill over into the more public zones of life. Experimental reports aimed at the gentlemanly public include descriptions of private spaces such as the larder and the bedchamber; details of private activities including undressing, sleeping, and defecating; and objects connected to private activities, e.g. chamber pots. ${ }^{7}$ Conversely, the public pursuits of science influence the behaviour within private spaces and condition the handling of objects found within private homes. Rather than being in opposition to or in tension with the public, the privacy inherent in Boyle's nocturnal experiments contributes to public knowledge generated by the larger scientific community.

This article examines how the entangled worlds of the public and private in early modern experimental philosophy, as observed in Boyle's report, mapped onto the satiric landscape of the late seventeenth century. As will be seen, contemporary satire of science feeds on the interaction between the public and private by relying on the circumstantial experimental report that was generated in private spaces and broadcast to the educated public. In experimental reports, the represented private spaces reveal everyday occurrences in the lives of experimental philosophers. These mundane aspects gain significance by becoming crucial components of scientific discovery. The mundane/ momentous distinction arises from the private/public contrast. ${ }^{8}$ Quick to seize on the creative potential of the mundane/momentous semantic pair, satire hijacks the lucid veal chops and common chamber pots from the published empirical reports and transforms them into vehicles of mockery. Whereas satire of the public aspects of the early modern experiment has received its fair share

4 Pollock L.A., "The Concept of Privacy in Early Modern England", in Wilson A. (ed.), Rethinking Social History: English Society 1570-1920 and Its Interpretation (Manchester: 1993) 86.

5 Boyle, "Some Observations about Shining Flesh" 5108.

6 Coppola A., The Theater of Experiment: Staging Natural Philosophy in Eighteenth-Century Britain (Oxford: 2016) 36 .

7 Again, servants would access these spaces as well as witness certain private activities.

8 See Bruun's contribution to this volume. 
of scholarly attention, ${ }^{9}$ satire arising from the privacy of the experiment warrants further research.

\section{Privacy in the Early Modern Experiment}

Seventeenth-century Europe witnessed the institutionalisation of systematic scientific experimentation. In the case of England, the Royal Society of London for Improving Natural Knowledge evolved from the informal meetings of scholars at Gresham College in the 1640s and received its Royal Charter in 1662. ${ }^{10}$ The Society held formal meetings, kept public records of their activities, and disseminated findings through their appointed printers. In short, the legitimacy of the Society's experimental claims depended upon its public presence.

Trust played a crucial role within the Royal Society and English experimental philosophy in general in the period. Practitioners relied on gentlemanly social codes that privileged truth-telling and thus ensured the validity of their testimony." In order for a scientific claim to be considered a 'matter of fact', direct witnessing of credible gentlemen was needed. This direct witnessing could be achieved by a demonstration of an experiment in the public rooms of the Royal Society. Thomas Sprat $\left(1635^{-1713}\right)$ describes the process of demonstration concisely in his 1667 apologia for the Society's activities and goals:

Those, to whom the conduct of the Experiment is committed, being dismiss'd with these Advantages, do (as it were) carry the eyes, and the imaginations of the whole company into the Laboratory with them. And after they have perform'd the Trial, they bring all the History of its process back again to the test. Then comes in the second great Work of the Assembly; which is to judge, and resolve upon the matter of Fact. In this

See, for example, Horne W.C., "Curiosity and Ridicule in Samuel Butler's Satire on Science", Restoration 7 (1983) 8-18; Shanahan J., "Theatrical Space and Scientific Space in Thomas Shadwell's Virtuoso", Studies in English Literature 1500-19oo 49 (2009) 549-571; Coppola A., "Retraining the Virtuoso's Gaze: Behn's Emperor of the Moon, The Royal Society, and the Spectacles of Science and Politics", Eighteenth-Century Studies 41 (2008) 481-506.

10 There are extensive studies on the early years of the Royal Society. A useful start is Michael Hunter's seminal work Establishing the New Science: The Experience of the Early Royal Society (Woodbridge: 1989). For more recent studies, see Skouen T. - Stark R. (eds.), Rhetoric and the Early Royal Society: A Sourcebook (Leiden: 2015) and Lynch W.T., Solomon's Child: Method in the Early Royal Society of London (Stanford, CA: 2001).

11 On the evolution of the concept of testimony in the early modern period, see Serjeantson R., "Testimony and Proof in Early-Modern England", Studies in History and Philosophy of Science 30 (1999) 195-236. 
part of their imployment, they us'd to take an exact view of the repetition of the whole course of the Experiment [...] never giving it over till the whole Company has been fully satisfi'd of the certainty and constancy; or, on the otherside, of the absolute impossibility of the effect. This critical, and reiterated scrutiny of those things, which are the plain objects of their eyes; must needs put out of all reasonable dispute $[\ldots] .^{12}$

Sprat explains the process whereby an experimental philosopher first prepares trials in private and then brings them for demonstration in front of a number of witnesses, who 'take an exact view of the repetition of the whole course of the Experiment'. The experiment is replicated, scrutinised, and judged. Sprat emphasises the importance of seeing: the experimental proceedings have to become 'plain objects of their [the witnesses'] eyes'. Further on, Sprat states that the level of credibility is proportionate to the number of witnesses: 'the concurring Testimonies of three-score or an hundred' ${ }^{13}$ will be worth more than a testimony of two or three people.

However, not all types of experiments were suitable for public demonstration. Some trials required an outdoor space, such as experiments with ballistics or falling objects. Similarly, certain indoor experiments, involving microscopical, telescopical, or anatomical procedures, could not easily be replicated or observed by a room full of witnesses. ${ }^{14}$ Thus, although the Royal Society placed great emphasis on science as a public and collaborative enterprise, many experiments still had to be conducted in privacy or in semi-private experimental spaces that included household servants and laboratory technicians. Accordingly, the rooms of the Royal Society constituted just one experimental site in seventeenth-century England. ${ }^{15}$

As C.C. Barfoot notes, a number of experiments of the period 'were carefully considered reports of experiences in the natural world we all inhabit, and required neither a laboratory nor the special equipment of a virtuoso. In many instances, all that was required was a particular occasion or a series of events

12 Sprat Thomas, The History of the Royal Society of London, for the Improving of Natural Knowledge (London, J. Martyn: 1667) 99. Emphasis in the original.

13 Ibidem, 100.

14 For a good overview of the types of experiments demonstrated in public and the record of the Society's minutes, see Hall M.B., Promoting Experimental Learning: Experiment and the Royal Society (1660-1727) (Cambridge: 1991).

15 Shapin S., "The House of Experiment in Seventeenth-Century England", Isis 79 (1988) 373404. See also Preston C., "A Blessing in the Wilderness': Fictions of Polity and the Place of Science" in her The Poetics of Scientific Investigation in Seventeenth-Century England (Oxford: 2015) 90-157. 
and the determination to make exact observations.16 A servant frightened by a shining piece of flesh was one such occasion. Therefore, the private residences of gentlemen constituted a significant site of experimentation.

The immediate challenge to a private experiment was the absence of credible witnesses who could validate scientific knowledge and produce indisputable 'matters of fact'. The clue to Boyle's solution to this problem can be gleaned from the above passage from Sprat. Instead of bringing his experiments to his audience, Boyle brought the audience to his experiments. With the help of an experimental report, Boyle was able to 'carry the eyes, and the imaginations of the whole company into the Laboratory' with him. The reader's physical absence from the experimental scene could thus be compensated for by their mental presence. Steven Shapin and Simon Schaffer have termed this strategy the literary technology of a virtual witness. ${ }^{17}$

Virtual witnessing signifies 'the production in a reader's mind of such an image of an experimental scene as obviates the necessity for either direct witness or replication'.18 A reader of an experimental report is thus able to indirectly witness the private experiment and validate its claims based on the given details. This technique also allows for a theoretically unlimited number of witnesses, which cannot be said of a public demonstration. To ensure valid judgment, no potentially meaningful detail should be left out of the account.

Boyle's report of his series of nocturnal experiments with the shining veal rests on this technology of virtual witnessing. ${ }^{19}$ The report consists of no less than eighteen numbered observations that include minute detail of the experiment conducted in privacy. The first point identifies the meat as 'a Neck of Veal, which, as I learned by inquiry, had been bought of a Country-butcher on the Tuesday preceding. ${ }^{20}$ The ensuing points communicate sensory information to the readers, who can feel as if they are standing next to Boyle in the night of the discovery.

The reader is transformed into a virtual witness by first being offered visual data. Boyle enumerates the places in which the meat shone as well as the sizes

16 Barfoot C.C., “'The Eunuch's Child': William King's Transactions with the Royal Society”, in Tinkler-Villani V. - Barfoot C.C. (eds.), Restoring the Mystery of the Rainbow: Literature's Refraction of Science, vol. 1 (Leiden: 2011) 73-92.

17 Shapin S. - Schaffer S., Leviathan and the Air-Pump: Hobbes, Boyle, and the Experimental Life (Princeton, NJ: 1985) 60-65.

18 Ibidem, 6o.

19 For a corpus-based linguistic approach to the language of Royal Society prose, see the article by Hogarth A.J. - Witmore M., "Reflexive Witnessing: Boyle, the Royal Society and Scientific Style", Notes and Records: The Royal Society Journal of the History of Science 74.1 (2020) 131-148.

$20 \quad$ Boyle, "Some Observations about Shining Flesh" 5108. 
of these 'Lucid parts. ${ }^{21}$ The parts that shone most were 'some gristly or soft parts of the bones, where the Butcher's Cleaver had passed'.22 Next comes the description of Boyle's experimental action: 'by good fortune having by me the curious Transactions of this month, I was able so to apply that flexible paper to some of the more resplendent spots, that I could plainly read divers consecutive letters of the Title. ${ }^{23}$ The exact issue of the journal is considered to be a relevant piece of information. Boyle reports that the colour that accompanied the light was not everywhere the same, but was 'fine Greenish blew' in those parts that shone the liveliest. ${ }^{24}$ The visual data is followed by tactile information, describing the heat of those parts. ${ }^{25}$ The olfactory data comes last, with the added statement that no ill scent from the meat could be observed. ${ }^{26}$

The in-depth account of the chop is followed by Boyle's detailed depiction of the spatial setting, which carries 'the eyes, and the imaginations of the whole company' into his larder:

9. The floar of the Larder, where this meat was kept, is almost a story lower then the level of the street, and 'tis divided from the Kitchen but by a partition of boards, and is furnished but with one window, which is not great, and looks towards the street, that lyes North-ward from it. ${ }^{27}$

The description provides a partial layout of Boyle's home. The reader can visualise the larder in the basement, partitioned from the kitchen by planks and having a small window looking northward onto the street. Indeed, the reader is even made to experience the meteorological conditions:

10. The wind, as far as we could observe it, was then at south-west, and blustering. The air, by the seal'd thermometer, appeared hot for the season. The moon was past its last quarter. The mercury in the barometer stood at $29^{3 / 16}$ inches. $^{28}$

$\begin{array}{ll}21 & \text { Ibidem, 5109. } \\ 22 & \text { Ibidem, 5109. } \\ 23 & \text { Ibidem, 5109. } \\ 24 & \text { Ibidem, 5109. } \\ 25 & \text { Ibidem, 5110. } \\ 26 & \text { Ibidem, 5110. } \\ 27 & \text { Ibidem, 5110. } \\ 28 & \text { Ibidem, 5110. }\end{array}$


The reader is transported into the private space of Boyle's home. As if standing in Boyle's larder, one can sense the blustering wind, feel the hot air, see the moon through the window, and read the barometer.

In the ensuing points, Boyle rubs and compresses the pieces of meat, and pours wine and water over them to observe the changes. Then, he reports his experiment with a 'Pneumatical Engine' so 'that the Experiment might be tryed in a greater degree of darkness: ${ }^{29}$

having conveyed one of the largest luminous pieces into a small Receiver, we caused the candles to be put out, and the pump to be plied in the dark [...] I could perceive, upon the gradual withdrawing of the Air, a discernible and gradual lessening of the light; which yet was never brought quite to disappear (as I long since told you the light of Rotten Wood and Gloworms had done). ${ }^{30}$

Boyle's pneumatic experiment is interrupted by a private detail: 'the unseasonable time of the night reducing me at length to go to bed, I could not stay to prosecute this or any other tryal. ${ }^{31}$ However, in the subsequent point Boyle recounts how, 'whilst I was undressing', it occurred to him that 'there might be in the same Larder more joints of the same Veal than one, innobled [sic] with this shining faculty. ${ }^{32}$ Accordingly, a leg of veal is brought into his chamber, and he observes that it is much less luminous than the neck.

In the final observation, No. 18, Boyle tells us how he could not perform any more experiments in the morning because he was woken before dawn on account of his dying niece. Still, 'whilst they were bringing me Candles for to rise by, I looked upon a clean phial, that I had laid upon the bed by me after a piece of our luminous Veal had been included in it, and found it to shine vividly at that time, which was between four and five of clock this morning.33 In her analysis of Boyle's experiments at home, Claire Preston pinpoints the issue that is at stake here: 'philosophical concerns seem to interfere with possibly prevent - normal diurnal patterns by confusing the place of work with the place of sleep' ${ }^{34}$ Boyle's detailed account shows the inextricable role of the private and the mundane in his scientific experimentation: he shares his bed with the veal chops.

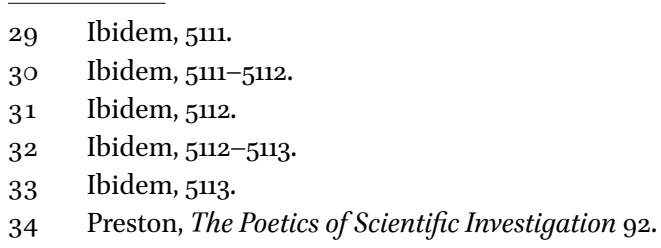




\section{$2 \quad$ Satire of the Experimental Report: Playing with Privacy}

As we have seen, Boyle's report uses 'a technology of trust and assurance that the things had been done and done in the way claimed'. ${ }^{35}$ However, in this attempt to ensure the legitimacy of his scientific claims and in his emphasis on the private circumstances, Boyle inadvertently provided fodder for contemporary satire. With their 'reflexive witnessing'36 and their wealth of circumstantial detail, his private nocturnal investigations inspired a satirical episode in Thomas Shadwell's The Virtuoso (1676). This comedy, centred around Sir Nicholas Gimcrack, pokes fun at ridiculous and useless experimentation frequently associated with the Royal Society. Most literary critics of the play have focused on the theatrical performance and spectacle of Gimcrack's scientific experimentation. ${ }^{37}$ However, Shadwell also satirises the more private aspects of seventeenth-century experimental philosophy. A gentleman asks Gimcrack:

BRUCE.

Is that all the use you make of these Pneumatick Engines? SIR NICHOLAS.

No; I eclipse the light of rotten Wood, stinking Whitings and Thornback, and putrid Flesh when it becomes lucid.

LONGVIL.

Will stinking Flesh give light like rotten Wood?

SIR NICHOLAS.

O yes; there was a lucid Surloin of Beef in the Strand, foolish people thought it burnt, when it onely became lucid and chrystalline by the coagulation of the aqueous Juice of the Beef, by the corruption that invaded it. 'Tis frequent. I my self have read a Geneva Bible by a Leg of Pork. BRUCE.

How, a Geneva Bible by a Leg of Pork?

SIR NICHOLAS.

O Ay, 'tis the finest Light in the World. ${ }^{38}$

35 Shapin - Schaffer, Leviathan and the Air-Pump 6o.

36 See Hogarth - Witmore, "Reflexive Witnessing: Boyle, the Royal Society and Scientific Style".

37 See e.g. Shanahan J., "Theatrical Space and Scientific Space in Thomas Shadwell's Virtuoso" and Coppola A., "The Spectacle of Experiment: The Politics of Virtuoso Satire in the 1670s" in his The Theater of Experiment: Staging Natural Philosophy in Eighteenth-Century Britain (Oxford: 2016) 32-62.

38 Shadwell Thomas, The Virtuoso (London, Henry Herringman: 1676) Act v, Scene ii. 
This discordant association between the Holy Bible and a mundane leg of pork is a result of Gimcrack's private trials. The private act of reading a Bible in one's home becomes a scientific matter of fact and transcends the private sphere by virtue of Gimcrack's testimony. The designation of the type of Bible is a spoof on Boyle's identification of the precise issue of Philosophical Transactions that he read by the light of the veal. The origin of Gimcrack's meat, as Peter Anstey has noted, ${ }^{39}$ has been lifted from Dr. John Beal's letter on luminescence, where he speaks of 'a piece of Fresh Beef, which shined in the Strand in London', and a woman and her husband who thought that it was on fire. ${ }^{40}$ Gimcrack's explanation that he uses his pneumatic engines 'to eclipse the light of rotten Wood, stinking Whitings and Thornback, and putrid Flesh when it becomes lucid' refers to Boyle's trial with the air pump quoted above, when he observed 'a discernible and gradual lessening of the light' of the veal.

Charles Sackville, the Earl of Dorset (1643-1706), ingeniously uses the motif of putrid and lucid veal to satirise Katharine Sedley, the Countess of Dorchester, in the last stanza of his poem 'On the Countess of Dorchester' (1680). Wondering why the countess insists on beautifying herself with 'embroid'ry, fringe, and lace' when she is so irreversibly old and pox-ridden, he concludes:

So have I seen in larder dark

Of veal a lucid loin,

Replete with many a heatless spark,

As wise philosophers remark,

At once both stink and shine. ${ }^{41}$

In his satire on the putrid countess, Sackville relies on the nightly privacy of Boyle's discovery. A shining piece of meat can be discerned in the darkness of the larder, and it reminds him of his addressee, who stinks in her disease and old age while shining in her outward appearance. 'Many a heatless spark' refers to Boyle's observation No. 7 , in which he writes that 'notwithstanding the vividness of this Light, I could not by the touch discern the least degree of Heat'.42 This reference indicates Sackville's intimate knowledge of the report,

39 Anstey P., "Literary Responses to Robert Boyle's Natural Philosophy", in Cummins J. Burchell D. (eds.), Science, Literature and Rhetoric in Early Modern England (Aldershot: 2007) 147 .

Beal John, "Two Instances of something Remarkable in Shining Flesh", Philosophical Transactions 11.125 (22 May 1676) 6oo.

41 Sackville Charles, The Poems of Charles Sackville, Sixth Earl of Dorset, ed. B. Harris (London: 1979) 45-46.

Boyle, "Some Observations about Shining Flesh" 5110. 
although, for satiric purposes, he changes Boyle's statement that the meat had no ill scent.

The method of including circumstantial particulars in experimental reports is not exclusive to Boyle, but is characteristic of the majority of the contributions to the Philosophical Transactions in the period. This apparent overflow of information was to become a satiric target of William King (1663-1712), one of the Christ Church wits. King's favourite satiric strategy was parodying the reports published in the Royal Society's journal by closely mimicking their language and style. The case of King is particularly significant in the light of his direct attack on the process of virtual witnessing and its circumstantial reporting.

In 1700, King published The Transactioneer, a pair of mock-scientific dialogues between a 'Gentleman' and a 'Virtuoso', and a 'Gentleman' and a 'Transactioneer'. The latter character is an embodiment of Sir Hans Sloane, secretary of the Royal Society and editor of the Philosophical Transactions. ${ }^{43}$ One look at King's table of contents reveals his main objects of attack in the Society's journal: King's topics include accounts of the extraordinary and improbable, such as 'A Foetus 16 Years in Utero'; of the obvious, e.g. 'That Men can't swallow when they're dead' or 'That Coffee-Houses promote the Trade of News Papers, and make People sociable'; and of the mundane, such as 'A pair of Brass Tweezers'. These mock-papers raise questions of testimony and truth regarding the reported experiments.

In his satirical attacks on the Royal Society, King sees the excessive particulars as unnecessary and trivial details rather than as signals of truthfulness. It is instructive to compare an original account of accidental poisoning published in the Philosophical Transactions with King's parody of it:

Between Pentsants and Macketjew, Mr. John Hancock, an Apothecary lived one Charles Worth an Apothecary, who causing a Pye to be made of the said Poppy - and eating of the said Poppy Pye, whilst hot, was presently taken with such a kind of a Dilirium, as made him fancy that most that he saw was Gold, and calling for a Chamber-pot, being a White in Pensants, gave me the following account of its Effects on one Charles Worth, and others of his Family, dwelling at the Half-way House between Pensants and Marketjew, (viz.) That the said Charles Worth, causing a Pye to be made of the Roots of the said Poppy, supposing them to be Sea-Holly

43 In 1709, King published a continuation of his attacks in three successive issues, entitled Useful Transactions in Philosophy, and Other Sorts of Learning (London, Bernard Lintott: 1709). 
Earthen one, after having purged by stool into it; he broke it into peices, and bid the by-standers to save them, for they were all Gold. or Eringo Roots (for that by order of a Physician lately lodging at his House, they had made Pies thereof, which was very pleasant to them) but he eating of the aforesaid Poppy Pye (whilst hot) was presently taken with such a kind of Delirium as made him fancy that most what he saw was Gold, and calling for a Chamber Pot, being a white Earthen one, after having purged by Stool into it, he broke it into pieces, and bid the By-standers to save them, for they all were Gold, as was also (as he said) all the Pewter in the house (he then pointing to it).

We would expect the paragraph on the left to be the original, and the one on the right a parody. In fact, it is the other way round. On the left is King's parody, ${ }^{44}$ and on the right is the original account written by James Newton and published in 1698 as 'An Account of some Effects of Papaver Corniculatum luteum' ${ }^{45}$ King's parody does not reach the heights of circumstantial detail present in the original. Granted, King recounts that the apothecary consumed the poppy in the form of a hot poppy pie. But so does Newton. Likewise, both reports take pains to recount the colour and material of the chamber pot into which the apothecary defecates: that this common household item was a 'w/White Earthen one' seems to be consequential to the narrative. However, Newton outstrips King in the wealth of detail, recounting the fact that the pie was made from the poppy roots, the origin of the mistake, the pleasantry of making pies during a physician's stay at his house, and the fact that the delirious man pointed at all the pewter in the house.

The sheer amount of detail in Newton's account makes it difficult for King to parody him. Instead of embellishing his parody with even more particulars than those employed by Newton, King's satiric strategy consists in directing the reader to the precise issue of the journal ('N. 242') where Newton's original is to be found. Upon reading King's parody and then consulting the original, the reader can more clearly observe the excess of detail in Newton's account,

\footnotetext{
44 King William, The Transactioneer. With some of his Philosophical Fancies: In two Dialogues (London, n.p.: 1700) 39 .

45 Newton James, "An Account of some Effects of Papaver Corniculatum luteum", Philosophical Transactions 20.242 (31 Dec 1698) 263-264.
} 
including the pervasive use of parentheses, which is already noticeable in Boyle. Unlike Jonathan Swift, who uses exaggeration to satirise the Grand Academy of Lagado in Gulliver's Travels, King resorts to minimalism in order to raise the reader's awareness of the cluttered nature of the original text. To King, Newton's account seems already at the point of absurdity.

The significance of the details in King's version escapes the understanding of the Gentleman, King's alter ego in the dialogues:

Gent. Methinks your Correspondent is very Circumstantial in relating the Circumstances and Symptoms of the Dilirium. ${ }^{46}$

The Gentleman uses plain language to unmask the unnecessary circumstantiality of the heard account. The Transactioneer is, however, quick to respond:

Transact. O dear Sir! There was an absolute necessity to be exact in Particulars, for had he only told us, that the Herb Purged and caused a Dilirium, how must we have known that he made use of an Earthen Chamber-Pot, that he purged into it, and then broke it.

Gent. Truly as you say we should have been altogether at a loss there: And to speak Truth; the most diverting Circumstances would have been wanting.

Transact. Yes, The Pleasant Circumstances set off the Story, for People purge into Chamber-Pots and are Dilirious, that never took Papaver Corniculatum. ${ }^{47}$

The Transactioneer insists on the relevance of the irrelevant: instead of taking the detail of the chamber pot as an indication of the account's authenticity, he transforms it into the centrepiece of the report. He takes care to emphasise the mundaneness of the reported activities ('for People purge into Chamber-Pots and are Dilirious, that never took Papaver Corniculatum'). The absurdity continues as the Gentleman asks:

Gent. But pray, What does this contribute to the Advancement of Natural Knowledge?

Transact. If it encreases Knowledge, it certainly advances it: And pray, Does not a Man know more that knows the Chamber-Pot was broke, than he that hears of a Dilirium, and purging? ${ }^{48}$

\footnotetext{
$46 \quad$ King, The Transactioneer 39 .

47 Ibidem, 39-40.

48 Ibidem, 40.
} 
The Transactioneer mistakenly equates the increase of knowledge with its advancement. What King sees as negligible circumstantial detail is taken as a valuable contribution to knowledge. The Transactioneer seems to be in accord with an anonymous opinion expressed during the early debates on the Royal Society's research programme: 'so far as we have any matter of fact before us, we have really advanced further than we were before. And many things which seeme trivial in them selves, may be a foundation for that which is of greater moment'. ${ }^{49}$ King, however, guides the reader to see the absurdity of a mere accumulation of claims and underlines the contrast between the mundane and 'that which is of greater moment'.

King's discussion of the chamber pot criticises the idea that verisimilitude can be achieved by a recital of every possible detail from the experimental scene as this will only lead to banal excess. What Boyle, Newton, and other experimental philosophers of the time saw as 'credentials that established the actuality of the event [...] all serving to add verisimilitude, 50 in Peter Dear's words, King saw as clutter. For him, this clutter of res and verba muddles the clarity of the report and distracts the reader from that which is relevant.

Importantly, in his satire of the experimental report, King seems to anticipate the direction in which scientific discourse was going to develop. ${ }^{51}$ In satiric form, he recognised that the abundance of detail in the contemporary reports does not create a 'concrete reality', as envisioned by Roland Barthes. ${ }^{52}$ In other words, for King, a sense of reality of the experimental scene does not necessarily come from a list of personal afflictions (such as the dying niece) and household items. Rather, these details only draw the reader's attention away from that which is relevant in the experiment.

All three satirists therefore use the serious experimental report to build their own playground of private experimentation and public demonstration. They challenge the truthfulness of the experimental data collected in private and mock its supposed public role. In their satiric works, contemporary experimental philosophy is reduced to nighttime Bible readings, mystical visitations to the larder, and anecdotal poisonings.

49 Royal Society Misc. Ms 4.72, quoted in Ibidem, 347. As quoted in McKeon M., The Secret History of Domesticity: Public, Private, and the Division of Knowledge (Baltimore, MD: 2005) 66.

$5^{\circ}$ Dear P., "Totius in verba: Rhetoric and Authority in the Early Royal Society", in Skouen Stark (eds.), Rhetoric and the Early Royal Society 66.

$5^{1}$ See Gross A.G. - Harmon J.E. - Reidy M.S., Communicating Science: The Scientific Article from the 17th Century to the Present (Oxford: 2002).

52 Barthes R., "The Reality Effect" in his The Rustle of Language, trans R. Howard (New York: 1986) 141-148. 
In seventeenth-century experimental philosophy, the zones of the public and private are not demarcated by a rigid boundary. Ideas, activities, and objects move across the zones and their different spatial registers as private individuals participate in a collaborative enterprise. The public pursuit of science regulates behaviour in private and, vice versa, private surroundings and objects influence the development of science. This interaction is manifested in the period's experimental report, which enables the reader to enter the experimental philosophers' private spaces and witness their mundane activities.

From Shadwell's oxymoronic reading of the Geneva Bible by the light of the pork, through Sackville's entry into Boyle's dark larder, and finally to King's parody of Newton, the inclusion of mundane details into the public form of the experimental report provided ample material for contemporary satire. Private activities and personal effects loom large in Shadwell's comedy and Sackville's verse, while in King's 'transactions' true knowledge drowns in circumstantial detail that originated in private spaces of experimental philosophers.

Contemporary satiric texts demonstrate the complexity of the notion of privacy in the case of early modern experimental practice. They question the process by which private or semi-private circumstances are received as relevant public knowledge. In the hands of satirists, experimental reports become a matter of hear-say or a list of useless data, where chops and chamber pots reign supreme.

\section{Selected Bibliography}

Barfoot C.C., “The Eunuch's Child': William King's Transactions with the Royal Society”, in Tinkler-Villani V. - Barfoot C.C. (eds.), Restoring the Mystery of the Rainbow: Literature's Refraction of Science, vol. 1 (Leiden: 2011) 73-92.

Black A., "The Orator in the Laboratory: Rhetoric and Experimentation in Thomas Shadwell's The Virtuoso", Restoration 37 (2013) 3-17.

Boyle Robert, "Some Observations about Shining Flesh", Philosophical Transactions 7.89 (16 December 1672) 5108-5116.

Coppola A., The Theaterof Experiment:Staging NaturalPhilosophyin Eighteenth-Century Britain (Oxford: 2016).

Cummins J. - Burchell D. (eds.), Science, Literature and Rhetoric in Early Modern England (Aldershot: 2007).

Henderson F., Erudite Satire in Seventeenth-Century England (Ph.D. dissertation, Monash University: 2002). 
Hogarth A.J. - Witmore M., "Reflexive Witnessing: Boyle, the Royal Society and Scientific Style", Notes and Records: The Royal Society Journal of the History of Science 74.1. (2O2O).

King William, The Transactioneer. With some of his Philosophical Fancies: In two Dialogues (London, n.p.: 1700).

Lynch W.T., Solomon's Child: Method in the Early Royal Society of London (Stanford, CA: 2001).

McKeon M., The Secret History of Domesticity: Public, Private, and the Division of Knowledge (Baltimore, MD: 2005).

Newton James, "An Account of some Effects of Papaver Corniculatum luteum", Philosophical Transactions 20.242 (31 Dec 1698) 263-264.

Preston C., The Poetics of Scientific Investigation in Seventeenth-Century England (Oxford: 2015).

Sackville Charles, The Poems of Charles Sackville, Sixth Earl of Dorset, ed. B. Harris (London: 1979).

Shadwell Thomas, The Virtuoso (London, Henry Herringman: 1676).

Shanahan J., "Theatrical Space and Scientific Space in Thomas Shadwell's Virtuoso", Studies in English Literature, 1500-1900 49 (2009) 549-71.

Shapin S., "The House of Experiment in Seventeenth-Century England", Isis 79 (1988) 373-404.

Shapin S. - Schaffer S., Leviathan and the Air-Pump: Hobbes, Boyle, and the Experimental Life (Princeton, NJ: 1985).

Skouen T. - Stark R. (eds.), Rhetoric and the Early Royal Society: A Sourcebook (Leiden: 2015). 